\title{
胃癌における漿膜下の微小血管形態と再発形式との検討
}

\author{
日本大学第 1 外科 \\ 西尾 知 天野定雄福澤 正洋
}

\section{Relationship between Subserosal Microvessel Profile and Recurrent Types in Gastric Cancer}

\author{
Satoshi NISHIO, Sadao AMANO and Masahiro FUKUZAWA \\ First Department of Surgely, Nihon University School of Medicine
}

胃癌の腹膜再発に関与する因子を子㨽する目的で腫瘍先進部におけるVEGF (vascular endotherial growth factor), u-PA (urokinase-type plasminogen activator) の免疫組織学的発現および腫场先進部漿謨下層の微 小血管断面檯率の面から，予後と再発形式について組織学的深達度mp, ss, seの胃癌組織111例を对象に比較検討 を行った。梁達度mp, ss, seにおいて癌性腹膜炎症例で徹小血管断面積率が高く，深達度mp，ssにおいて微小血 管断面稳率が高い拝例は有意に予後不良であった。VEGF, u-PAについては非再発群に比べなんらかの再発をき たした症例は染色车が高くなる傾向が見られたが，深達度および再発形式により一定しなかった。以上より胃癌 原発巣奬膜下層における微小血管断面稹率の測定は腹膜再発予測因子として，また子後因子として有用である可 能性が示唆された。

霜引用浯：胃癌 (gastric cancer)，微小血管断面積率 (microvessel area rate), 腹膜再発 (peritoneal recurrence)

\section{はじめに}

胃癌の再発形式として腹膜播種性転移は最も多 く，一度再発するとその治療には難渋することが 多い。近年の分子生物学の進歩により，血管透過 性元進作用をもつ血管新生因子が胃癌の進展に関 与することが報告されている1。

血管新生の最初のステップとして血管の拡張が おこるが, 内皮細胞は扁平で未熟であり, 安定化 が行われていないために血管の透過性が立進して いると考えられる。腫瘍の血管新生に関しても， その過程における血管の搪張, 透過性の元進と腹 水産生の関連性が報告されている ${ }^{2)-5) 。 ~}$

このような背景から胃癌術後の腹膜再発におい て，腫瘍の新生血管は血管透過性が穴進しており 癌性腹水の産生と腹膜播種をきたす可能性が考之
られる。そこで初回手術時の胃癌先進部漿謨下層 の微小血管の形態に着目して，一定面積における 微小血管断面積率 (microvessel area rate略して MVAR) を算出して, 予後と再発形式と比較検討 を行った。また細胞外マトリックスの消化に重要 なプロテアーゼである urokinase-type plasminogen activator (以下u-PA) ${ }^{67)}$ や血管内皮細 胞增殖因子であるvascular endtherial growth factor (以下VEGF) ${ }^{8)}$ の免疫組織学的発現と再発 形式の関係についても合わせて検討した。

\section{対象}

1974年 1 月から1995年12月までの間に当教室で 治瘾手術を行い, 術後 5 年間の経過が明らかな原 発性進行胃癌111症例を対象とした。

男女比は男性74例，女性37例であり，年龄分布 


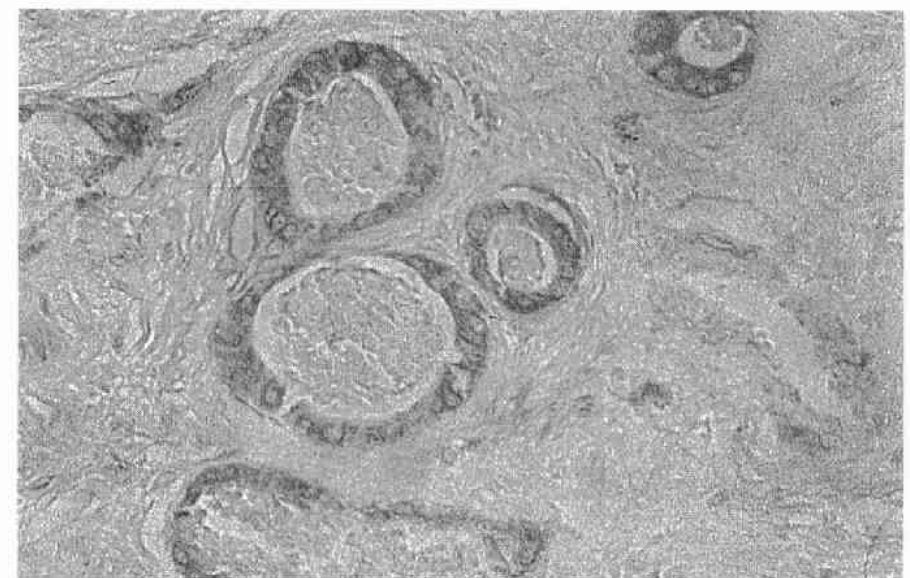

A : VEGF $(\times 200)$

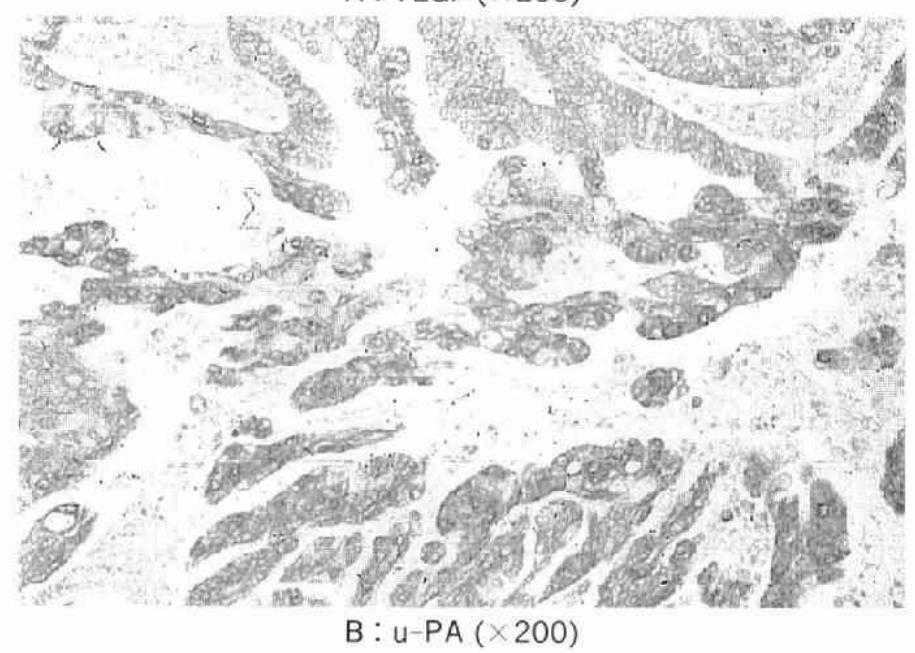

Fig. 1 Immunohistochemical stainings with VEGF and u-PA in cancerous tissue.

The expression of VEGF (A) and u-PA (B) was shown by brownish staining in the cytoplasm of the cancer cells.

は22歳から83歳で, 平均62.6歳であった。胃癌取 扱い规約第 13 版 ${ }^{9} に$ 従ったこれらの背景因子では 深達度別ではmp症例21例，ss症例53例，se症例 37 例であり, stage分類ではstage I 14例, stageII 29 例, stageIII36例, stageIV32例であった。

非再発例 (以下C群) は54例, 再発例は57例で, 細胞診で診断の確定した腹膜再発例 (以下P群) は 42 例, その他の肝転移, 肺転移、リンパ節転移の 再発形式 (以下R群) が15例であった。

\section{方法}

\section{1 免疫組織染色}

腫揘の先進部のパラフィン包埋標本より作成し た $4 \mu \mathrm{m} の$ 連続切片を用いて streptavidin-biotin complex (SAB) 法にて間接免疫酵素体法を行っ た。脱パラフィン後, $3 \% \mathrm{H}_{2} \mathrm{O}_{2}$ 加リン酸緩衝生理 食塩水 (以下PBS) にて内因性ペルォキシターセ の不活性化を施行した。PBSにて洗浄後，10\%+ ギまたはウサギ止常血清に公温にて30分漬け，非 特異反応をブロックした。その後, 一次抗体とし て抗VEGF polyclonal抗体 (Santa-Cruz社) 100 
a)

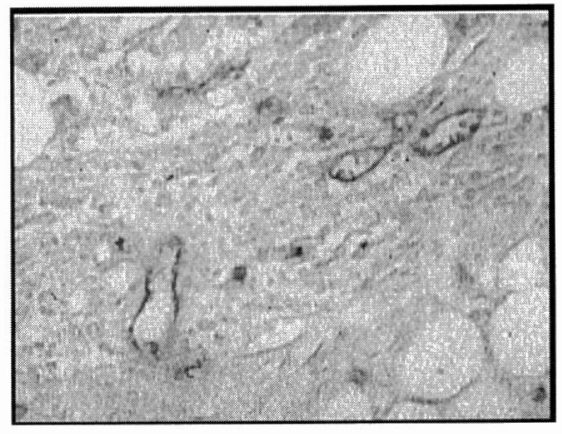

c)

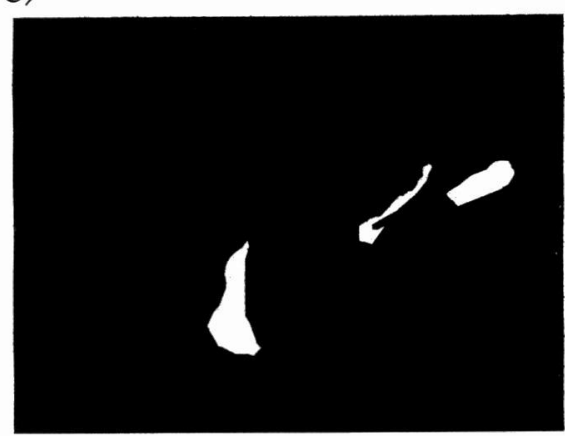

Fig. 2 Method of measuring MVAR

a) Immunohistochemical staining with von Willebrand factor in cancerous tissue. The expression of the von Willebrand factor was shown by dark staining at microvessel ( $\times 200)$.

b) The lumen of the minute blood vessel surrounded in vascular endothelial cells stained with von Willebrand factor was traced by the image analysis equipment.

c) The field incorporated in the image analysis equipment was divided into lumen of the blood vessel and background part. Afterwards, MVAR was calculated. This measurement was carried out in the 5 visual fields of the hot spot, and the mean value was made to be MVAR.

倍希橎，抗 u-PA monoclonal抗体 (American Diagnosic社) 100倍希釈, 抗von Willebrand因子 polyclonal抗体 (Dako社) 100倍希釈を用い, $4{ }^{\circ} \mathrm{C}$ でover nightで反応させた。PBSにて洗浄後, VEGF，von Willebrand因子はbiotin化ヤギ抗ウ サギIgG，u-PAはbiotin化ウサギ抗マウス IgG+ IgA+IgMを室温で30分反応させ, 再度PBSにて 洗浄し peroxidase-conjugate streptavidin（二チ レイ, ヒストファイン社) と反応させた。発色に は $\mathrm{H}_{2} \mathrm{O}_{2}$ 加 diaminobezidineを用いた。 positive controlとして各実験毎にVEGF, u-PA, von
Willebrand因子染色が強陽性に認められる組織 を同時染色した。またnegative controlとして10\% ウサギ正常血清を 1 次抗体として用いた。

\section{2 染色性の判定}

VEGF, u-PAの染色性 (Fig. 1) の判定は光学: 顕微鏡下で, 癌先進部 5 視野を観察し, VEGF, u -PA染色陽性細胞を 1,000 個以上計測し, 平均して 癌細胞の細胞質が $10 \%$ 以上染色されているものを 陽性と判定した。また腫瘍先進部漿膜下層におけ る微小血管断面積率の算出はvon Willebrand因 子染色の切片について200倍の倍率で一定面積 
$\left(0.624 \mathrm{~mm}^{2}\right)$ について画像解析装置（日本アビオ ニクス社：TV image processor EXCEL)を用い た。まず組織切片上の面像を取り込み，染色され た血管内皮細胞に囲まれた血管とそれ以外の組織 を2值化して血管面積の総和を計測し, 組織切片 上において血管面積の占める割合を血管断面積率 とした。この計测を 5 視野で行い平均值を求め微 小血管断面積率 (以下MVAR) とした (Fig. 2)。

MVAR, VEGF, u-PAの発現と臨床病理学的因 子, 特に再発形式を中心に検討した。2 群間の検 定にはStudent'st-testおよび $\chi^{2}$ 乗検定を用い， 3 群以上の検定には一元配置分散分析（1 way ANOVA) 後多重比較 (post hoc) としてBon ferroni法を用いた。また累積生存率の算出には Kaplan-Meier法を用い, 統計学的解析はlogrank 法またはgeneralized Wilcoxon法を用いpが0.05 以下のものを有意差ありと判定し, $\mathrm{p} か ゙ 0.10$ 以下 を傾向ありと判定した。

\section{成㙂}

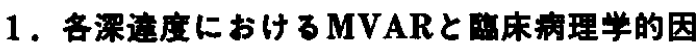 子の模讨}

MVARは最小 $0.6 \%$ ，最大 $30.2 \%$ の間に分布し

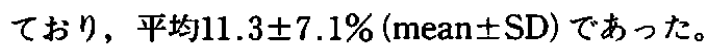
各深達度におけるMVARの值は深達度mp症例に

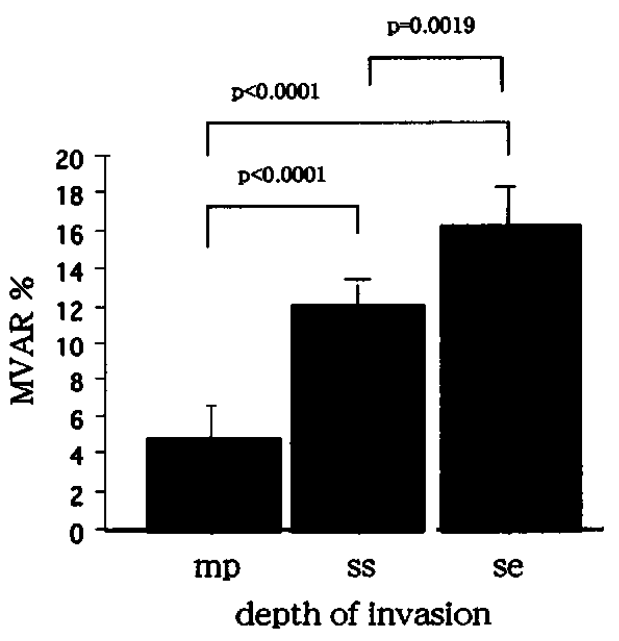

Fig. 3 Relations between the depth of inva. sion and MVAR in gastric cancer. There was positive correlation between the depth of invasion and MVAR.
おいて平均 $5.8 \pm 4.1 \%$ であり, ss症例において平 均 $11.2 \pm 6.9 \%$, se症例では平均 $15.1 \pm 6.4 \%$ であ ク，それぞれ 3 群間で解析を行ったところ, 深達 度が進むにつれてMVARは有意に高值となった (mp-ss間 : p $<0.0001, \mathrm{mp}-\mathrm{se}$ 間：p<0.0001, ss -se間：p<0.0019）（Fig.3）。

\section{2. 再発形式とMVARの検讨}

再発形式をC群, R群, P群の 3 群に分類し各深 達度におけるMVARを比較した。深達度mp群に

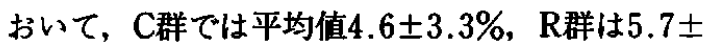
$3.2 \%$, P群では平均値 $10.5 \pm 3.9 \%$ と群より P群 は有意にMVARが高值となった（ $\mathrm{p}=0.0003 ）$

(Fig. 4)。

深達度ss群においてC群 (28例) では平均値 $7.0 \pm 4.1 \%$ ， R群 ( 5 例)では $12.5 \pm 4.2 \%$, P群 $(20$

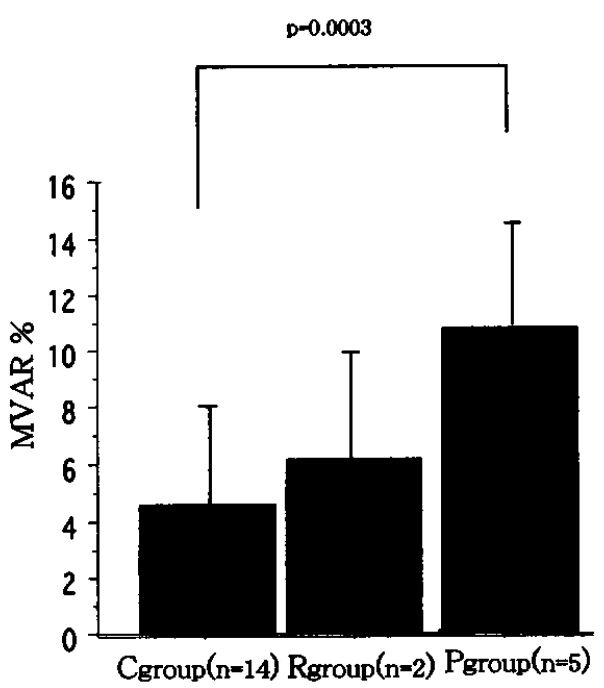

Fig. 4 Relations between reccurrent types of gastric cancer and MVAR in the cases with the depth of $\mathrm{mp}$ invasion.

In the cases of the peritoneal relapse ( $P$ group) in gastric cancer with tumor inva. sion to $\mathrm{mp}$.

MVAR was significantly higher than nonrecurrent cases (C group). MVAR of the $P$ group tended to be higher than that of the other reccurent cases without peritoneal relapse ( $R$ group), whereas there was no statistical significance between these groups. 


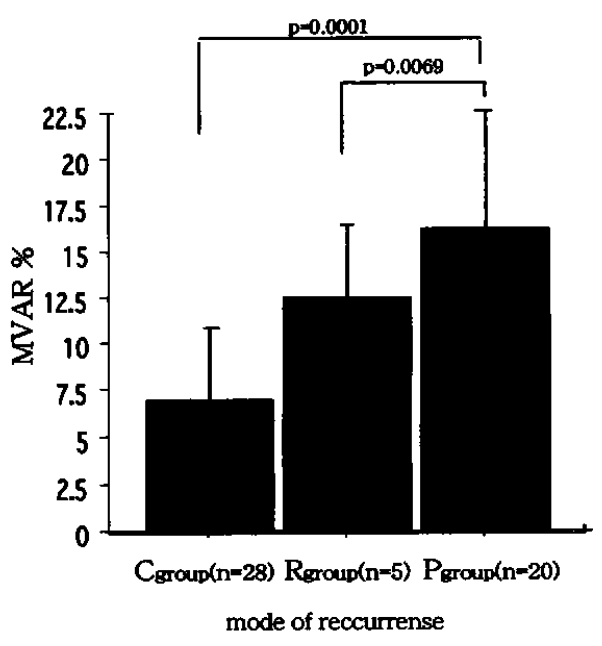

Fig. 5 Relations between reccurrent types of gastric cancer and MVAR in the cases with the depth of ss invasion.

In the cases of the peritoneal relapse ( $P$ group) with tumor invasion to $s s$, the microvessel area rate was significant higher than those of non-recurrent cases ( $C$ group) and otrer recurrent type cases ( $R$ group).

例)は15.9土7.3\%であった。P群はC群に比べ高值 （ $\mathrm{p}=0.0001 ） と な り ， P$ 群はまたR群に比べ有意 に高詙であった $(p=0.0069 ） （$ Fig.5 )。深達度se

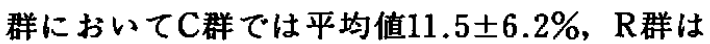
$15.8 \pm 3.9 \%$ ，P群は17.1士6.7\%であった。P群は C群にくらへて有意にMVARが高值となった $(\mathrm{p}=0.0107)$ (Fig. 6)。

\section{3. 采程生存率の検討}

MVARの平均值 $12 \%$ を境界とし $12 \%$ 以上を MVAR高值群 (62例)，それ未满をMVAR低值群 (49例) の 2 群に分類し, mp, ss, seの各群にお いて術後累積生存率を比較してみると, $\mathrm{mp}, \mathrm{ss} の$ 深達度において高値群は低值群に比へて有意に術 後累積生存率が不良であったが (Fig. 7, 8), se群 では高值群は術後累積生存率が不良の傾向があっ たが有意ではなかった（Fig.9）。

\section{VEGFの染色性と再発形式との娭期}

各梁達度別にVEGFの染色性と再発形式を検討 した。VEGFの免疫組織学的発現率はmp, ss, se の深達度別では各々 $43 \% ， 43 \% ， 57 \%$ で有意差は

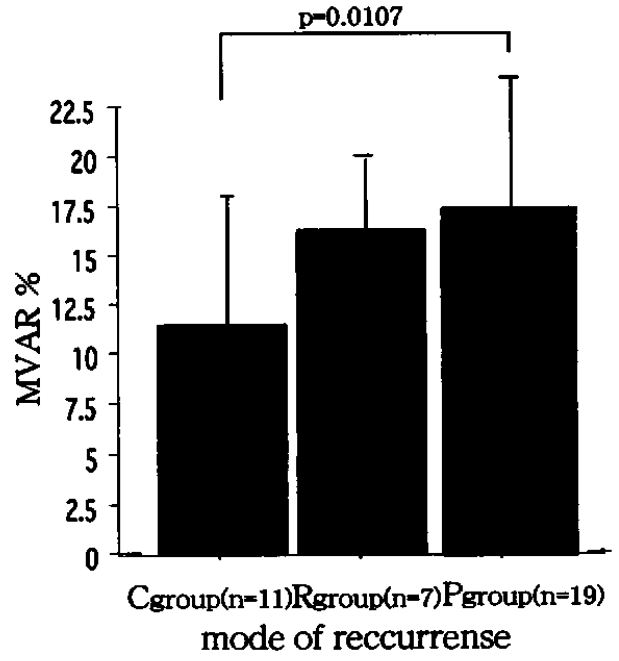

Fig. 6 Relations between reccurrent types of gastric cancer and MVAR in the cases with the depth of se invasion.

in the cases of the peritoneal relapse ( $P$ group) with tumor invasion to se. MVAR was significantly higher than non-recur. rent cases ( $C$ group).

MVAR of the $P$ group tended to be higher than that of the other recurrent type cases ( $R$ group), whereas there was no statistical significance between these groups.

なかった。再発形式とVEGF発現との検討では深 達度mpにおけるVEGF発現率はC群 $21 \%$ ， R 群50 \%，P群40\%で，C群とP群の間に有意差を認めた $(\mathrm{p}=0.024)$ 。深達度ssにおいてC群 $36 \%$ ，R群40 $\%$ ，P群55\%であり，P群はC群より有意に発現率 が高く $(\mathrm{p}=0.034)$, 深達度seではC群 $45 \%$, R 群71 $\%$ ， P群58\%であり各群間に有意差は認めなかっ た (Fig. 10)。

\section{5.u-PAの染色性と再発形式の湌付}

各深達度別にu-PAの染色性と再発形式を検討 した。u-PAの免疫組織学的発現率はmp, ss, seの 各深達度別では各々 $34 \% ， 34 \% ， 59 \%$ で有意差は なかった。再発形式とu-PA発現との検討では深 達度mpにおいてC群 $7 \%$ ， R群50\%，P群40\%で有 意差はなかった。梁達度ssにおいてC群14\%，R群 40\%，P群60\%であり $\mathrm{P}$ 群はC群より有意に発現率 が高かった $(\mathrm{p}=0.0013)$ 。深達度seではC群54\%， R群 $57 \%$ ，P群 $63 \%$ であり，非再発例にくらべて再 


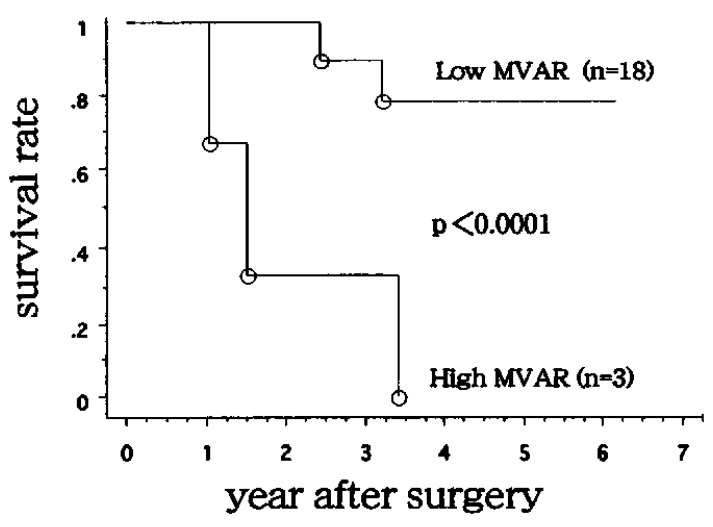

Fig.7 Survival rate for MVAR in the cases with tumor invasion to $\mathrm{mp}$.

The patients were divided into two groups: high MVAR ( $\geqq 12 \%$ ) and low MVAR ( $<12 \%)$.

Survival rate was significantly worse in the patients with high MVAR than those with low MVAR. The probability value was calculated by Generalized Wilcoxon test.

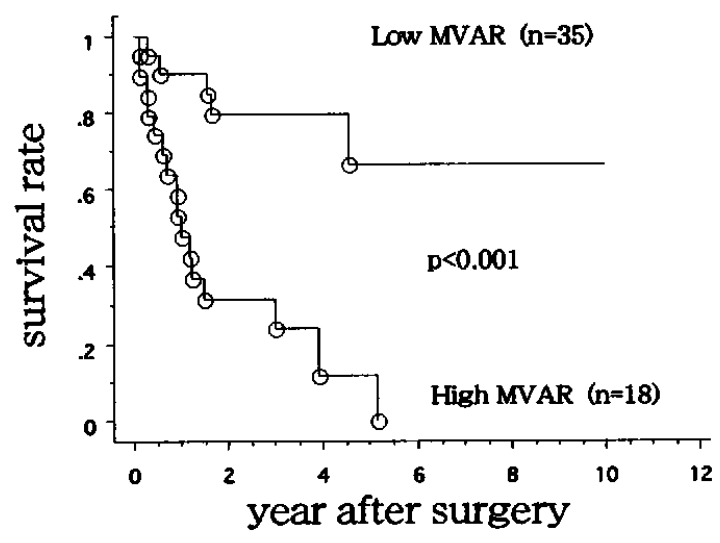

Fig. 8 Survival rate for MVAR in the cases with tumor invasion to ss.

The patients were divided into two groups: high $\operatorname{MVAR}(\geq 12 \%)$ and low MVAR $(<12 \%)$.

Survival rate was significantly worse in the patients with high MVAR than those with low MVAR. The probability value was calculated by Generalized Wilcoxon test.

発例では発現率が高くなる傾向があったが各深達 度により一定しなかった（Fig.11）。

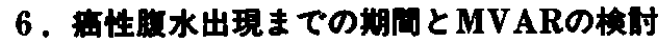

深達度ssにおいて癌性腹水出現までの期間が 1

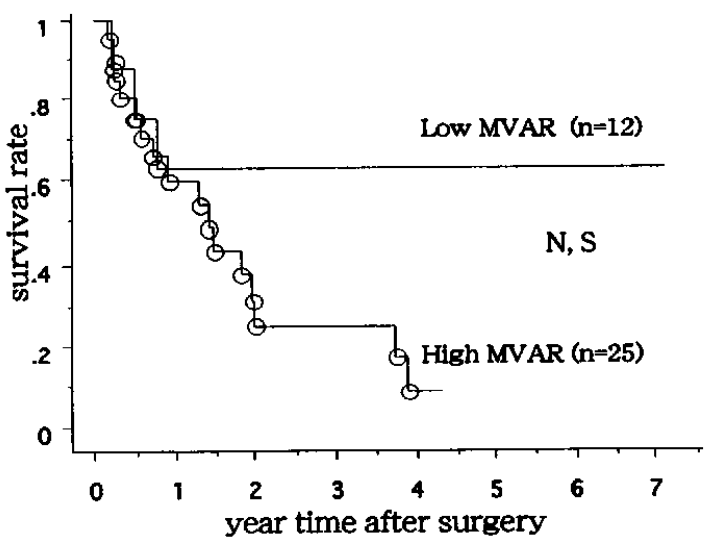

Fig. 9 Survival rate for MVAR in the cases with tumor invasion to se.

The patients were divided into two groups: high MVAR ( $\geqq 12 \%$ ) and low MVAR ( $<12 \%$ ).

there was no significancy between survival rate in the patients with high MVAR and those with low MVAR. The probability value was calculated by Generalized Wilcoxon test.

年未満の早期再発群と 1 年以上の晚期再発群の 2 群に分け，それぞれのMVARについて検討した。 早期再群は $21.0 \pm 6.6 \%$, 晚期再発群で $14.5 \pm 5.5$ \%と早期再発群はMVARが有意に高值であった （p=0.0217）（Fig.12）。MVAR21\%をこえる場 合， 1 年以内の早期に癌性腹膜炎型再発をきたす ものと推察された。

\section{考察}

MVARを測定する意義は, 血管新生の観察にあ ると考えられる。癌の進展に必要な形質は運動性 の元進と細胞外マトリックス ${ }^{100} の$ 分解である。細 胞外マトリックスを分解する蛋白分解酵素が転 移，進展に際して癌細胞から分泌される。また分 解された間質内へ成長した血管新生が成熟するた めには内皮細胞の增殖，平滑筋や周細胞による被 覆安定化が必要といわれている。この過程では, 血管の形態が変化し透過性が六進しているものと 仮定し, 漿膜下の血管の形態に着目して検討した。

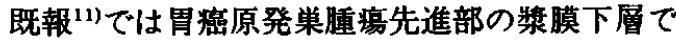
のMVARと腹膜再発との関連性を検討した。その 結果, MVARは腹膜再発と関連性が認められ, 深 達度とも強い相関があった。今回は更に各深達度 

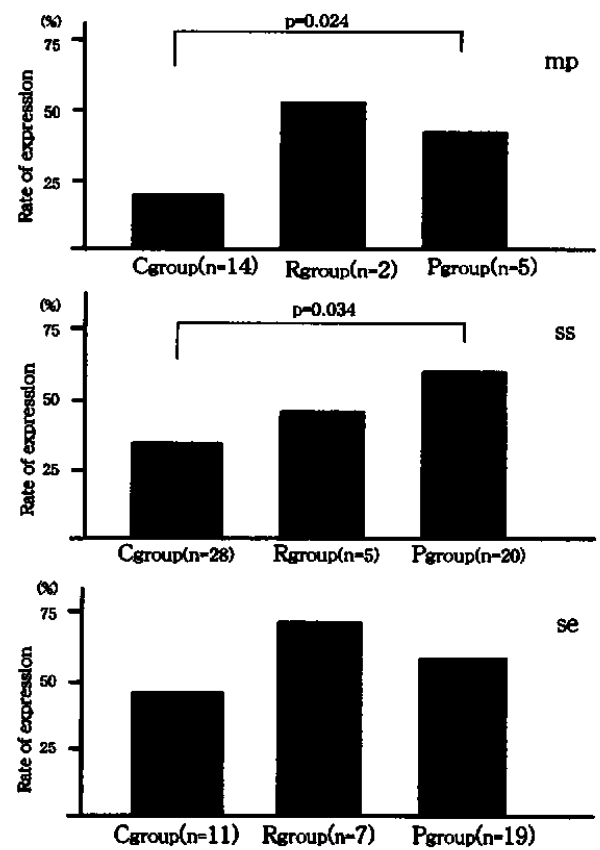

Fig. 10 The relations between patterns of reccurrence and the expression rate of VEGF according to the depth of tumor invasion.
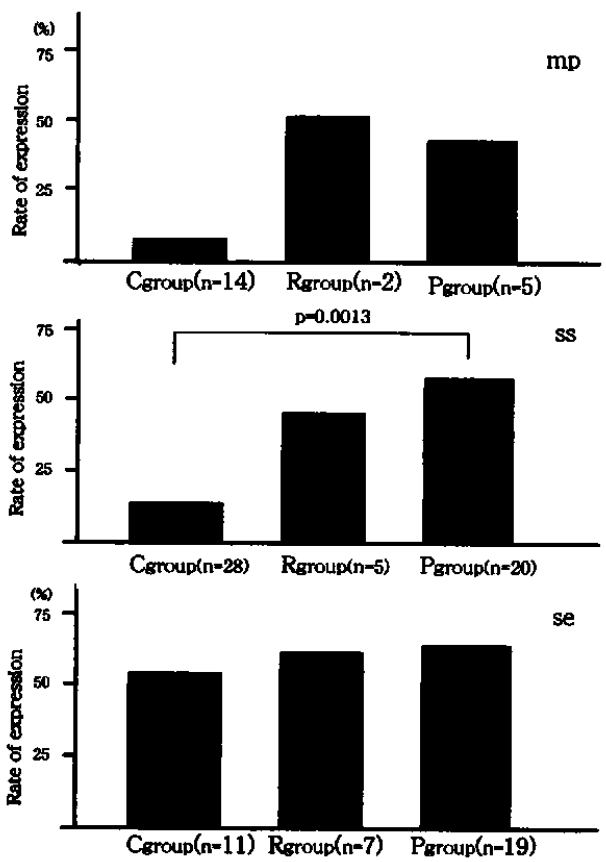

Fig. 11 The relations between patterns of reccurence and the expression rate of $\mathrm{u}-\mathrm{PA}$ according to the depth of tumor invasion.

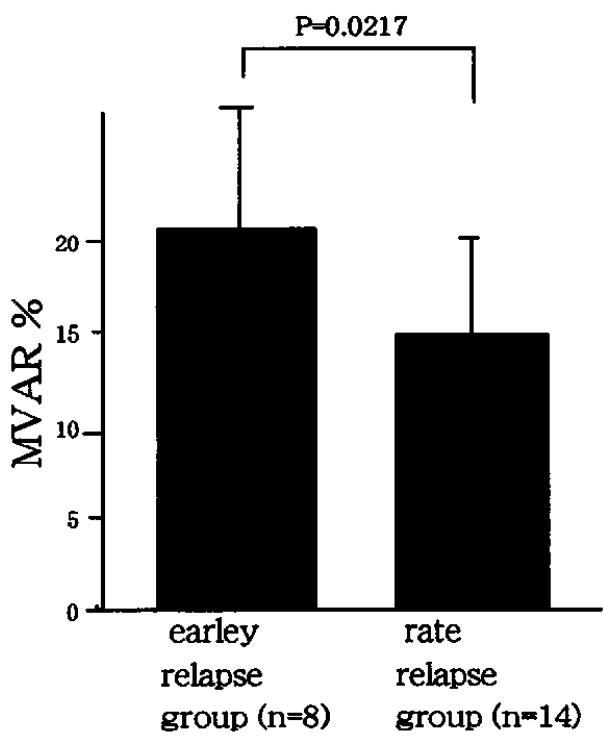

Fig. 12 The relations between MVAR and the period till peritoneal relapse in the cases with tumor invasion to ss.

In the early peritoneal relapse group which recurred within 1year after operation, MVAR tended to be significantly higher than that of the late peritoneal relapse group which recurred over 1 year.

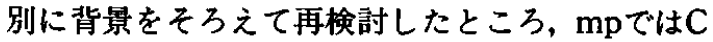
群とP群の間に有意差があり, ssではC群とP群, R 群とP群の間に有意差があり， seではC群とP群の 間に有意差があった。これらの成績は基本的に $\mathrm{P}$ 群が他の 2 群と比べMVARが大きいことを示し ており，再発形式の指標になることを示している。 またこれらの結果はse群の様に明らかに腹膜再発 の危険が高い群ではなく，ss群のように治癒の可 能性が高い群において再発形式を予測できるとい う特徴を示していた。 $\mathrm{mp}$ 群ではR群において証例 数が少なかったため統計では有意差がでなかった がss群と同様の傾向であると考えられる。

累積生存率についてもMVARはmp，ssにおい て予後因子として有用であり腹膜再発が直接予後 に結びつくことを示している。一方se群では腫瘍 織が明らかに腹空内に蕗出しているため臨床的な MVARの意義は低くなっていると考えられた。今 回, 再発形式とu-PAやVEGFの発現との関連性に ついての検討を行った結果では, mp群は有意差が 
なく, ss群ではu-PAとVEGFの発現でいずれもC 群とP群の間に有意差があり, se群ではVEGFの 発現でC群とP群の間に有意差があった。しかしい ずれの深達度においてもR群とP群の間に有意差 のある因子はなく, 腹膜再発の予想にはMVARが これらの因子より優れていることが示唆された。

現在, 腹膜再発の予測因子として術中腹腔洗浄 細胞㟝が幅広く行われているが12)，細胞診の判定 は陽性，陰性の 2 種であり再発までの期間 (disease free interval) を検討しているものは少ない。 深達度ssにおけるP群において 1 年未満の早期再 発群と 1 年以上の晚期再発群に分けて検討したと ころ, 早期再発群においてMVARが有意に高值と なることが判明した。すなわちこの結果はMVAR が再発形式を予測し，加えて再発時期も予测でき ることを示唆するものと考えられた。今回の成樍 から今後の課題として迅速凍結病理検查の手法を もちいて手術終了までに槳膜下層のMVARを測 定し, 腹暯再発のハイリスク群 (特にss群) と判定 された症例では温熱水還流化学療法などの集学的 治療の適応を決める良い方法となるのではないか と考えている。今後, 術中細胞診の成績とあわせ て検討を重ねていきたい。

\section{结㟽}

進行胃癌の槳嗼下層の微小血管断面積率は胃癌 の腹膜再発の予測因子となる可能性が示唆され た。

\section{考考文献}

1) 荒谷宗充, 阿部 黄, 寺島雅典：胃癌における腫 痬血管新生に関する検討. 岩手医誌49：405-416, 1997

2) Janice AN, Michelle SM, Elizabeth MM, et al : Pathogenesis of Ascites Tumor Growth: Fibrinogen Influx and Fibrin Accumulation in Tissues Lining the Peritoneal Cavity. Cancer Res $55: 369-375,1995$
3) Janice AN, Elizabeth MM, Kemp TH, et al : Pathogenesis of Ascites Tumor Growth : Vascular Permeability Factor, Vascular Hyperpermeability, and Ascites Fluid Accumulation. Cancer Res $55: 360-368,1995$

4) Janice AN, Ellen SM, Kemp TH, et al : Pathogenesis of Ascites Tumor Growth : Angio genesis, Vascular Remodeling, and Stroma Formation in the Peritoneal Lining. Cancer Res 55 : 360-368, 1995

5) Peter Carmeliet : Mechanisms of angiogenesis and arteriogenesis. NATURE MEDICINE vol 6 April 2000

6) Cho JY, Chung HC, Noh SH, et al : High Level of urokinase-type plasminogen activator is a New Prognostic Marker in Patients with Gastric Carcinoma. Cancer $79: 878-883,1997$

7）冨松姶一，市會 隆，玉熊让说：ss青癌における urokinase-type plasminogen activator $と$ type 1 plasmiogen activator inhibitorの発現一肝再発 予湘としての有用性. 日消外会誌 $28 ： 1662-1672$, 1995

8) Maeda K, Yong-suk Chung, Ogawa Y, et al : Prognostic Value of Vascular Endothelial Growth Factor Expression in Gastric Carcinoma. CANCER $77: 858-868,1996$

9）胃癌研究会編：畧癌取扱規䄪. 改訂第12版, 金原 出版, 東京, 1993

10) Lance A Liotta, C N Rao, Sanford H Barsky : Tumor Invasion and the Extracellular Matrix. Laboratry Investigation $49: 636-649,1983$

11）西尾 知, 天野定雄，桜井健一他：胃癌における 癌性腹水再発予測因子に関する免疫組織学的検 討一血管密度, 血管断面積涐, VEGFについて(第 一報)。Biotherapy12：1149-1156, 1998

12）中島聡總, 及川隆司, 大橋一郎他: 進行胃癌にお ける術中腹腔細胞診の烸床的意義. 癌の臨 $23: 27$ -34, 1977 